\title{
Limited potential for terrestrial carbon sequestration to offset fossil-fuel emissions in the upper midwestern US
}

\author{
Cinzia Fissore ${ }^{1, *}$, Javier Espeleta ${ }^{1,2}$, Edward A Nater ${ }^{1}$, Sarah E Hobbie ${ }^{3}$, and Peter B Reich ${ }^{4}$
}

\begin{abstract}
Many carbon dioxide $\left(\mathrm{CO}_{2}\right)$ emission-reduction strategies currently under consideration rely on terrestrial carbon $(\mathrm{C})$ sequestration to offset substantial proportions of $\mathrm{CO}_{2}$ emissions. We estimated $\mathrm{C}$ sequestration rates and potential land areas for a diverse array of land-cover changes in the Upper Midwest of the US, a "best case" region for this study because of its relatively modest $\mathrm{CO}_{2}$ emissions and the large areas of cropland potentially available for conversion. We then developed scenarios that apply some of the most widespread mitigation strategies to the region: the first, which aimed to offset $29 \%$ of regional $\mathrm{CO}_{2}$ emissions, required the unrealistic loss of two-thirds of working cropland; the second, which estimated the emission offset attainable by conversion of $10 \%$ of harvested croplands (5.8\% of the US total), resulted in $<5 \% \mathrm{CO}_{2}$ emissions reduction for the region $(<1.1 \%$ of total US emissions). There is limited capacity for terrestrial $\mathrm{C}$ sequestration, so strategies should aim to directly reduce $\mathrm{CO}_{2}$ emissions to mitigate rising atmospheric $\mathrm{CO}_{2}$ concentrations.
\end{abstract}

Front Ecol Environ 2010; 8(8): 409-413, doi:10.1890/090059 (published online 15 Dec 2009)

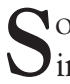
ocietal concern over global warming and its link to ncreasing atmospheric carbon dioxide $\left(\mathrm{CO}_{2}\right)$ concentrations has motivated many local communities, states, and countries to develop plans to reduce net fluxes of $\mathrm{CO}_{2}$ to the atmosphere. These plans involve two general strategies: (1) direct reduction of fossil-fuel-based $\mathrm{CO}_{2}$ emissions through enhanced energy conservation and efficiency and development of alternative energy sources; and (2) sequestration of atmospheric carbon (C) in standing biomass or C-depleted agricultural soils through changes in land cover or management practices, such as the conversion of annual row crops to perennial vegetation (forest or grassland) or adoption of agricultural practices, such as conservation tillage, that are thought to promote net $\mathrm{C}$ storage (Paustian et al. 1998; Six et al. 2002; Niu and Duiker 2006).

The Intergovernmental Panel on Climate Change (IPCC 2007), among others, points to afforestation and other changes in land use as potential ways to offset part of current $\mathrm{CO}_{2}$ emissions worldwide. Mitigation plans drafted by several US states also rely on terrestrial $\mathrm{C}$ sequestration for a large proportion, or even the majority of net $\mathrm{CO}_{2}$ flux reductions. For example, the Minnesota Climate Change Advisory Group (MNCCAG 2008) proposes that terrestrial $\mathrm{C}$ sequestration will account for $38 \%$ of Minnesota's projected $2025 \mathrm{C}$ emission-reductions strategy; the Montana Climate Change Action Plan (2007) proposes to offset $11 \%$ of its C emissions by terrestrial sequestration by 2020; and the Idaho Soil

${ }^{1}$ Department of Soil, Water, and Climate, University of Minnesota, St Paul, MN *(fisso001@umn.edu); ${ }^{2}$ University of Arizona Biosphere 2, Oracle, AZ; ${ }^{3}$ Department of Ecology, Evolution, and Behavior, University of Minnesota, St Paul, MN; ${ }^{4}$ Department of Forest Resources, University of Minnesota, St Paul, MN
Conservation Commission (2003) proposes that Idaho's fossil-fuel emissions can be offset almost entirely by changes in management practices and land cover.

While efforts to mitigate $\mathrm{C}$ emissions are needed, it is questionable whether terrestrial $\mathrm{C}$ sequestration can achieve such ambitious results, particularly in light of (1) the impacts of local strategies on the global food production system; (2) increasing pressures on agricultural lands from an array of competing sectors, including food and biofuel production and urbanization; and (3) burgeoning evidence that previously published rates of $\mathrm{C}$ sequestration attributed to the conversion from conventional tillage to no-till systems were overly optimistic. In fact, $\mathrm{C}$ sequestration rates may not differ substantially between alternative tillage practices (Baker et al. 2007; Blanco-Canqui and Lal 2008).

The purpose of this study was to provide a conservative estimate of the potential magnitude of $\mathrm{CO}_{2}$ emissions that could be offset by terrestrial $\mathrm{C}$ sequestration in the Upper Midwest of the US. For our analysis, we chose assumptions and situations that produced the most optimistic (ie largest) estimates of potential C sequestration, to ensure that we did not underestimate the magnitude of potential offsets. These included no reversal of land to previous land-cover type or management practice with low $\mathrm{C}$ stocks (eg croplands), no loss of $\mathrm{C}$ accrued in standing biomass by fire, disease, or insect invasion, no saturation of soil-C storage capacity, and no "leakage", whereby high C-stock lands outside the Upper Midwest (eg tropical forests) are converted to land uses that have lower C stocks (eg croplands) to counter losses of agricultural productivity resulting from our scenario conversions. The resulting estimates represent a reasonable maximum of potential $\mathrm{CO}_{2}$ emission offsets due to $\mathrm{C}$ sequestration for the region. 


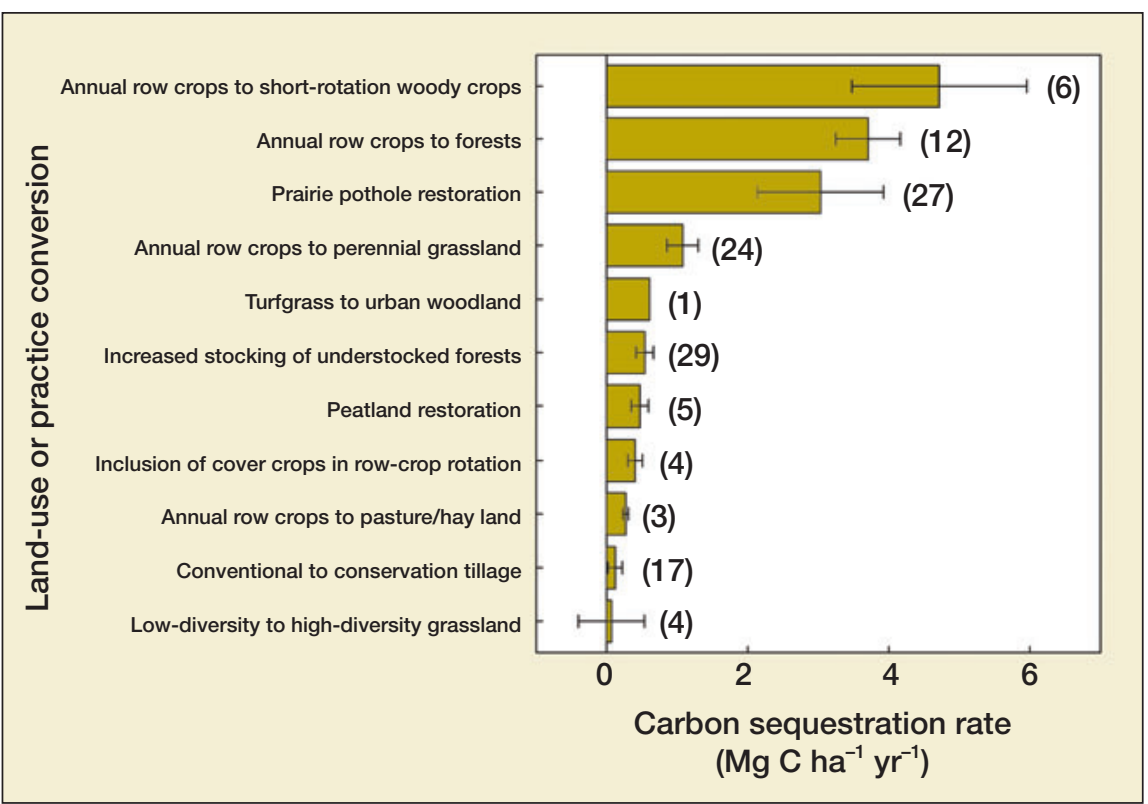

Figure 1. Estimated $\mathrm{C}$ sequestration rates $\left(\mathrm{MgC} \mathrm{Ca}^{-1} \mathrm{yr}^{-1}\right)$ associated with land-cover or land-management changes in the Upper Midwest of the US (see WebPanel 1). Estimates were obtained from published empirical studies for the Upper Midwest and other ecologically comparable locations. Carbon sequestration rates apply to a 50-year timeframe, with the exception of short-rotation woody crops, for which net $\mathrm{C}$ sequestration rate corresponds to the rotation time (harvest cycle of approximately 20 years) without accounting for the fate of harvested products or other $\mathrm{C}$ losses that would occur upon harvest. Bars are means \pm standard error; numbers in parentheses indicate number of observations.

This conservative estimate is developed in two contrasting land-cover and management-change scenarios (see WebPanel 1) that are based on mean C sequestration rates, calculated from a critical review of published empirical $\mathrm{C}$ sequestration values appropriate for the region. We deliberately excluded more complex models of land-cover and management changes in our analyses, because the added degree of refinement was unnecessary for the estimate we sought to develop. Existing estimates of regional emission-offset potentials either focused on very different ecological areas (eg Freibauer et al. 2004) or explored few land-use-change options, often relying on model results and assumptions of high $\mathrm{C}$ sequestration rates associated with reduced tillage practices (Freibauer et al. 2004; Jackson and Schlesinger 2004).

\section{Methods}

We selected the Upper Midwest of the US for our study region because it represents a "best case" scenario for the potential for $\mathrm{C}$ sequestration to offset greenhouse-gas (GHG) emissions. The geographic area considered (Indiana, Illinois, Iowa, Kansas, Michigan, Minnesota, North Dakota, Nebraska, Ohio, South Dakota, and Wisconsin) is a good test case for several reasons. First, it is characterized by a moderate (by US standards) C economy (378 $\mathrm{Tg} \mathrm{C} \mathrm{yr}^{-1}$ ); second, it covers a large area $\left(1770000 \mathrm{~km}^{2}\right)$, roughly comparable to the combined areas of France, Germany, Spain, and Italy; and finally, it is used intensively for agriculture, with nearly $73 \%$ of the land area being farmed (NASS 2002). Relative to the entire US, the Upper Midwest has approximately $23 \%$ of $\mathrm{C}$ emissions from fossil fuels, $19 \%$ of the total land area, $20 \%$ of the population, and $58 \%$ of the harvested cropland (annual crops: mainly corn, soybeans, and wheat; NASS 2002).

Because cultivated agricultural lands are often C-depleted, they have the potential to sequester $\mathrm{C}$ when converted to land-cover types that positively affect their net $\mathrm{C}$ balance. The potential for terrestrial $\mathrm{C}$ sequestration to offset current $\mathrm{C}$ emissions in the Upper Midwest region is high, resulting from the large proportion of harvested croplands relative to emissions. Prior to European settlement, the Upper Midwest was largely covered by vegetation types (forests, prairies, and wetlands) with high $\mathrm{C}$ stocks in standing plant biomass, peat, or soil organic matter. A large proportion of this area was converted into cropland (much of it artificially drained), with a corresponding reduction in biomass and, over time, soil-C stocks. The reversion of harvested croplands to these former (or structurally similar) land types should produce net $\mathrm{C}$ sequestration.

We used published data applicable to the region to derive mean $\mathrm{C}$ sequestration rates for the most common landcover and management changes proposed, and applied these rates to two hypothetical $\mathrm{CO}_{2}$ emission-reduction scenarios to estimate the terrestrial $\mathrm{C}$ sequestration potential for the region. Scenario 1 involves afforestation and restoration of perennial grassland as well as restoring prairie pothole wetlands, where ecologically feasible, and stocking all understocked forests in each state to achieve a total of $29 \% \mathrm{CO}_{2}$ emission offsets for the entire region (sensu Pacala and Socolow 2004). Scenario 2 involves the conversion of $10 \%$ of land currently used for agriculture into a combination of the practices stated above, to estimate the resulting $\mathrm{CO}_{2}$ emission reduction (see WebPanel 1).

\section{Results and discussion}

Mean $\mathrm{C}$ sequestration rates for different land-cover and management changes varied between 0.06 and $4.7 \mathrm{Mg} \mathrm{C}$ $\mathrm{ha}^{-1} \mathrm{yr}^{-1}$, with the highest rates (Figure 1) associated with the conversion of annual row-crop agricultural lands to short-rotation woody crops $\left(4.7 \mathrm{Mg} \mathrm{C} \mathrm{ha}^{-1} \mathrm{yr}^{-1}\right.$ before harvest), forest (3.7 Mg C ha $\left.\mathrm{yr}^{-1}\right)$, and restored prairie pothole wetlands $\left(3.1 \mathrm{Mg} \mathrm{C} \mathrm{ha}^{-1} \mathrm{yr}^{-1}\right.$ ). Conversion from 
cropland to forest achieved the highest rate of $\mathrm{C}$ sequestration during the 50-year projected timeframe of this study because of major $\mathrm{C}$ accumulation in standing biomass (Liski et al. 2002). The introduction of hybrid or other fast-growing tree species as short-rotation woody crops produces even higher terrestrial $\mathrm{C}$ sequestration rates over shorter timeframes (ie over the course of the crop rotation, typically less than 20 years), but a full C life cycle analysis of the fate of harvested woody products is necessary to project this sequestration estimate over time periods longer than a single rotation. Major soil-C sequestration rates are also associated with restored perennial grasslands (Tilman et al. 2001; McLauchlan et al. 2006).

The mean $\mathrm{C}$ sequestration rates of a number of other widely proposed land-cover and management changes are much more modest (between 0.1 and $0.6 \mathrm{Mg} \mathrm{C} \mathrm{ha}^{-1} \mathrm{yr}^{-1}$; Figure 1), and for some of these practices, namely conversion from low- to high-diversity grassland and from conventional to conservation tillage, the variability is so great relative to the mean that one cannot determine whether net $\mathrm{C}$ sequestration actually occurs (Figure 1 ). In particular, $\mathrm{C}$ sequestration rates associated with the conversion from conventional to conservation tillage reported in 17 studies across the Upper Midwest were both negligible (mean $=0.1 \mathrm{MgC} \mathrm{ha}^{-1} \mathrm{yr}^{-1}$ ) and highly variable (ranging from -0.8 to $0.8 \mathrm{Mg} \mathrm{C} \mathrm{ha}^{-1} \mathrm{yr}^{-1}$ ). Recent studies indicate that conservation tillage is more likely to cause a redistribution of $\mathrm{C}$ within the soil profile than an overall accrual (Baker et al. 2007; Blanco-Canqui and Lal 2008).

Using these $\mathrm{C}$ sequestration rates (Figure 1; WebPanel 1 ), we elaborated two scenarios. Scenario 1 is based on the widely cited work of Pacala and Socolow (2004), whereas Scenario 2 is based on a somewhat more realistic, but still massive, conversion of cropland. Although arbitrary, both scenarios resemble land-cover and management-change scenarios suggested by currently proposed strategies (IPCC 2007; MNCCAG 2008). Mean C sequestration rates for some of the most ecologically feasible land-cover and management changes for the region were matched with current land-use inventories for agriculture, grassland, and forest, to calculate the potential area of land available for conversion and to develop C sequestration estimates.

\section{Scenarios}

\section{Scenario 1}

This seeks to quantify the land area necessary to sequester 29\% ( 106 $\left.\mathrm{Tg} \mathrm{C} \mathrm{yr}^{-1}\right)$ of 2004 regional C emissions (equal to two one-seventh fractions or "wedges" of the total 2004 emissions; sensu Pacala and Socolow 2004) through a combination of land-cover and management changes (Table 1) and their associated sequestration rates (Figure 1). We focused on those land-cover and management changes that have the greatest $\mathrm{C}$ sequestration rates that are ecologically feasible over large areas. Attaining a $29 \%$ emission reduction for the region would require converting 50 million ha (two-thirds) of existing agricultural land in the area into forests, grasslands, or prairie pothole wetlands, as ecologically appropriate, as well as enhanced stocking of 30 million ha of existing forests. The cropland acres lost in the Upper Midwest in this scenario constitute nearly $40 \%$ of the harvested cropland acres and a disproportionate $49 \%$ of all grain, oilseed, and dry bean production in the US, a huge economic loss impacting other sectors of the agricultural and food-processing industry dependent on these yields. The combination of practices assigned to each state, and the absolute and relative contributions in terms of $\mathrm{C}$ sequestration and mitigation potential attributed to them, are provided in Table 1.

The resulting figures are optimistic with respect to the magnitude of $\mathrm{C}$ sequestered per unit of land converted, for the reasons stated above. Furthermore, they assume that enhanced forest stocking will produce fully stocked forest stands; in reality, forests are generally "understocked" for a variety of reasons (poor, wet, or rocky soils; competition from dominant trees; disease and herbivory) that limit the establishment and growth of trees. Thus, the actual gains in stocking and in $\mathrm{C}$ sequestered would probably be considerably less than projected in this scenario; consequently, the area of land conversion required to achieve a $29 \%$ emission offset would be even larger.

\section{Scenario 2}

This estimates the proportion of regional $\mathrm{CO}_{2}$ emissions that could be offset if $10 \%$ of the total harvested cropland in each state in the region were converted to forests or grasslands, as ecologically appropriate; if additional land, equal to $10 \%$ of the original prairie pothole habitat, was restored; and if $25 \%$ of all currently understocked forests were successfully restocked. The absolute and relative contributions to $\mathrm{C}$ sequestration and mitigation potential estimated by state are provided in Figure 2. Converting the harvested cropland area ( 7.4 million ha) considered in this scenario would more than double the current (as of 2006) land area (6.35 million ha) set aside in this region through enrollment in the Conservation Reserve Program (US Department of Agriculture Farm Service Agency). Despite taking an enormous area of agricultural land out of production, this strategy would, at best, mitigate only $4.7 \%$ of current $\mathrm{CO}_{2}$ emissions for the region (Figure 2).

Both of the scenarios described above provide conservative estimates of the potential for GHG mitigation by land-cover and management change. Any scenario that removes large areas of agricultural land from production will greatly reduce global food supplies (Field et al. 2007), which are already insufficient to meet worldwide needs, and would most likely be countered by a corresponding conversion of forest or other high C-stock ecosystems elsewhere in the world into agricultural production. Deforestation is still occurring in various parts of the 


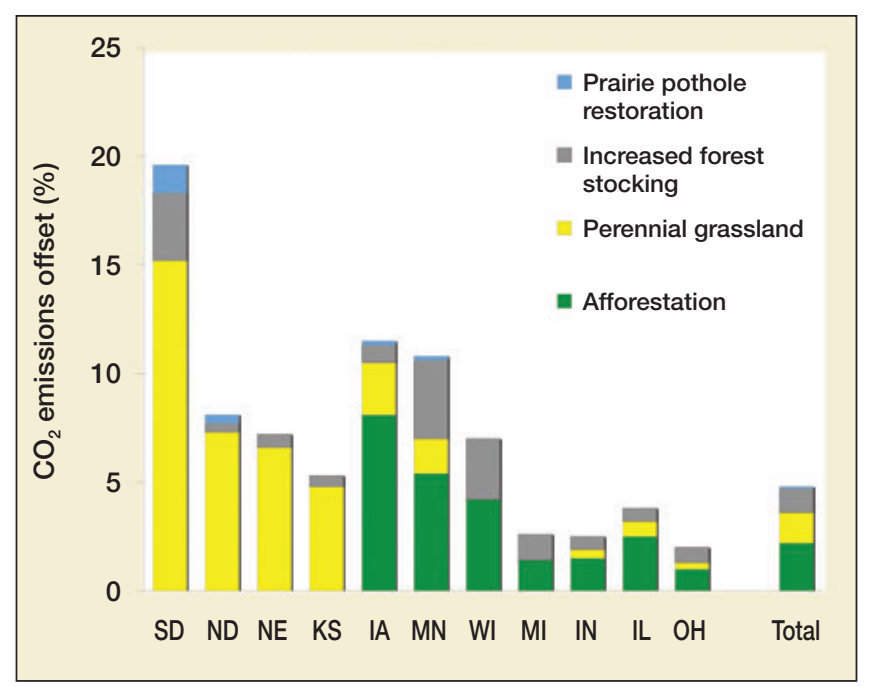

Figure 2. State-by-state potential of percent fossil-fuel $\mathrm{CO}_{2}$ emissions (2004) mitigation, as a result of converting $10 \%$ of harvested cropland, restocking $25 \%$ of understocked forests, and restoring 10\% of prairie potholes in the Upper Midwest of the US. A similar percentage of harvested cropland (10\%) was converted to forest and/or perennial grasslands in each state, depending on land availability and ecological suitability. Improved stocking refers to the restocking of $25 \%$ of currently understocked forests (50\% of all forest land). In four states within the prairie pothole region (MN, IA, SD, and ND), C sequestration from restoration of prairie pothole wetlands was calculated for an additional area of harvested cropland equivalent to $10 \%$ of presettlement prairie pothole area. States are ordered according to individual $\mathrm{CO}_{2}$ emissions, from low to high. Regional total estimates are also provided for comparison. world and further "leakage" would more than negate any net $\mathrm{C}$ emission reductions obtained by the initial conversion.

The scenarios described above use land-cover and management changes identified as providing the largest per hectare sequestration potential and that are ecologically feasible over extended areas in the region. Other landcover and management changes that were not included in these analyses would provide only modest $\mathrm{C}$ sequestration, even if applied over large areas, because their C sequestration rates are considerably lower (Figure 1).

Conservation tillage has received considerable attention in the past decade as a potential $\mathrm{C}$ sequestration tool, because of the possibility of applying this practice on vast areas of land (Lal 2004; Grace et al. 2006), while still maintaining those lands in agricultural production. Early estimates indicated that conservation tillage could offset a substantial proportion of total $\mathrm{C}$ emissions; however, those estimates were based on much higher $\mathrm{C}$ sequestration rates for conservation tillage than are currently believed to be true and on the conversion of more than 75\% of all cropland in the US to no-till by 2020 (Lal 1997). Similarly high estimates were based on models that predicted higher $\mathrm{C}$ sequestration in conservation tillage, based on assumed greater plant material return to soil than in conventional tillage (Grace et al. 2006). Applying the (highly uncertain) mean $\mathrm{C}$ sequestration rate for conservation tillage (Figure 1) that we obtained from empirical studies for the region to all harvested cropland in the Upper Midwest (circa 70 million ha [58\% of US cropland]) would sequester $8.4 \mathrm{Tg}$ of C, equivalent to only $2 \%$ of 2004 regional emissions, suggest-

\begin{tabular}{|c|c|c|c|c|c|c|c|c|}
\hline \multirow{3}{*}{ State } & \multicolumn{6}{|c|}{ C sequestration potential of land-cover and management change } & \multirow{3}{*}{$\begin{array}{c}\text { Fossil-fuel } \\
\text { emissions } \\
\text { (2004) } \\
\mathrm{Tg} \mathrm{CO} \mathrm{Cr}^{-1}\end{array}$} & \multirow{3}{*}{$\begin{array}{c}\text { Relative } \\
\text { emission } \\
\text { offset } \\
\%\end{array}$} \\
\hline & $\begin{array}{c}\text { Cropland area } \\
\text { converted } \\
(*)\end{array}$ & $\begin{array}{l}\text { Row crop to } \\
\text { forest }\end{array}$ & $\begin{array}{c}\text { Row crop to } \\
\text { perennial } \\
\text { grassland }\end{array}$ & $\begin{array}{l}\text { Prairie pothole } \\
\text { restoration } \\
(\dagger)\end{array}$ & $\begin{array}{l}\text { Optimal forest } \\
\text { stocking } \\
\text { (ग) }\end{array}$ & Total & & \\
\hline & \multicolumn{2}{|l|}{ Million ha } & \multicolumn{3}{|c|}{$\mathrm{TgCO} \mathrm{yr}^{-1}$} & & & \\
\hline Minnesota & 6.2 & 35.9 & \multirow[t]{3}{*}{10.5} & \multirow[t]{3}{*}{1.7} & 14.3 & 62.4 & 100 & 62 \\
\hline Wisconsin & 2.2 & 29.6 & & & 11.8 & 41.5 & 107 & 39 \\
\hline Michigan & 1.3 & 17.2 & & & 8.8 & 26.0 & 187 & 14 \\
\hline Illinois & 5.7 & 38.6 & \multicolumn{2}{|l|}{11.4} & 5.3 & 55.3 & 236 & 23 \\
\hline Indiana & 3.4 & 23.2 & \multicolumn{2}{|l|}{6.8} & 5.3 & 35.2 & 233 & 15 \\
\hline Ohio & 2.6 & 17.5 & \multicolumn{2}{|l|}{5.2} & 7.6 & 30.3 & 262 & 12 \\
\hline lowa & 7.3 & 43.1 & \multicolumn{2}{|l|}{12.7} & 2.5 & 60.0 & 80 & 75 \\
\hline South Dakota & 4.4 & & \multicolumn{2}{|l|}{13.8} & 1.7 & 17.3 & 14 & 126 \\
\hline North Dakota & 6.6 & & \multicolumn{2}{|l|}{22.7} & 0.8 & 25.2 & 47 & 54 \\
\hline Nebraska & 4.7 & & \multicolumn{2}{|l|}{19.0} & 1.0 & 20.0 & 43 & 47 \\
\hline Kansas & 6.1 & & \multicolumn{2}{|l|}{24.4} & 1.9 & 26.4 & 77 & 34 \\
\hline Regional total & 50.5 & 205.1 & 126.5 & 7.0 & 61.0 & 399.6 & 1386 & 29 \\
\hline
\end{tabular}


ing that previous projections of $\mathrm{C}$ mitigation resulting from conservation tillage have been overly optimistic.

\section{Conclusions}

The results of this study show that terrestrial $\mathrm{C}$ sequestration has, at best, only limited potential to offset GHG emissions for the Upper Midwest of the US, a region with moderate emissions and large areas of cropland. This potential for mitigation is tightly constrained by the relatively low areal $\mathrm{C}$ sequestration rates associated with most land-cover and management changes and the limited availability of C-depleted, non-agricultural lands for conversion to land-use and landcover types that have higher $\mathrm{C}$ sequestration rates. Any GHG mitigation scenario that takes large tracts of land out of agricultural production will very probably generate leakage elsewhere, thereby negating any potential benefits, unless major worldwide market regulations and policies are introduced in the near future to prevent leakage from happening.

Although some state policy reports have noted the modest $\mathrm{C}$ mitigation potential achievable through landcover and management changes (Center for Clean Air Policy 2005), others have viewed this potential as considerable (MNCCAG 2008). Regional estimates, like the one proposed here, represent a critical step toward the development of global-scale assessments of terrestrial C sequestration potential. This study highlights the need to develop accurate and realistic regional estimates of $\mathrm{C}$ sequestration potentials, as well as their capacity to mitigate current $\mathrm{C}$ emissions and their possible impacts on the world food supply, regional economies, and land-use activities elsewhere. Otherwise, overestimation of potential benefits from terrestrial $\mathrm{C}$ sequestration, such as those highlighted in this study, could potentially divert the attention of policy makers from other, more feasible, realistic, and cost-effective GHG mitigation strategies.

\section{Acknowledgments}

Funded by Minnesota Legislative authorization HF \#1666, 2007. We thank M Lennon for helping with data collection.

\section{References}

Baker JM, Ochsner TE, Venterea RT, and Griffis TJ. 2007. Tillage and soil carbon sequestration - what do we really know? Agric Ecosyst Environ 118: 1-5.

Blanco-Canqui H and Lal R 2008. No-tillage and soil profile carbon sequestration: an on-farm assessment. Soil Sci Soc Am J 72: 693-701.
Center for Clean Air Policy. 2005. Activities and policies to enhance forest and agricultural carbon sinks in California. Washington, DC: Center for Clean Air Policy.

Field CB, Campbell JE, and Lobell DB. 2007. Biomass energy: the scale of the potential resource. Trends Ecol Evol 23: 65-72.

Freibauer A, Rounsevell MDA, Smith P, and Verhagen J. 2004. Carbon sequestration in the agricultural soils of Europe. Geoderma 122: 1-23.

Grace PR, Colunga-Garcia M, Gage SH, et al. 2006. The potential impact of agricultural management and climate change on soil organic carbon of the north central region of the United States. Ecosystems 9: 816-27.

Idaho Soil Conservation Commission. 2003. Carbon sequestration on Idaho agriculture and forest lands. Boise, Idaho: Idaho Soil Conservation Commission.

IPCC (Intergovernmental Panel on Climate Change). 2007. Climate change 2007: mitigation. Contributions of Working Group III to the Fourth Assessment Report of the Intergovernmental Panel on Climate Change. Cambridge, UK: Cambridge University Press.

Jackson RB and Schlesinger WH. 2004. Curbing the US carbon deficit. P Natl Acad Sci USA 101: 15827-29.

Lal R. 1997. Residue management, conservation tillage and soil restoration for mitigating greenhouse effect by $\mathrm{CO}_{2}$-enrichment. Soil Tillage Res 43: 81-107.

Lal R. 2004. Soil carbon sequestration to mitigate climate change. Geoderma 123: 1-22.

Liski J, Perruchoud D, and Karjalainen T. 2002. Increasing carbon stocks in the forest soils of western Europe. Forest Ecol Manag 169: 159-75.

McLauchlan KK, Hobbie SE, and Post WM. 2006. Conversion from agriculture to grassland builds soil organic matter on decadal timescales. Ecol Appl 16: 143-53.

MNCCAG (Minnesota Climate Change Advisory Group). 2008. A report to the Minnesota Legislature. Saint Paul, MN: MNCCAG. www.mnclimatechange.us/MCCAG.cfm. Viewed 19 Oct 2009.

Montana Climate Change Action Plan. 2007. Final report of the Governor's climate change advisory committee. Helena, MT: Montana Climate Change Action Plan. www.mtclimatechange. us/CCAC.cfm. Viewed 19 Oct 2009.

NASS (National Agricultural Statistics Service). 2002. Census of agriculture, USDA. www.agcensus.usda.gov. Viewed 19 Oct 2009.

Niu XZ and Duiker SW. 2006. Carbon sequestration potential by afforestation of marginal agricultural land in the Midwestern US. Forest Ecol Manag 223: 415-27.

Pacala S and Socolow R. 2004. Stabilization wedges: solving the climate problem for the next 50 years with current technologies. Science 305: 968-72.

Paustian K, Cole CV, Sauerbeck D, and Sampson N. 1998. $\mathrm{CO}_{2}$ mitigation by agriculture: an overview. Climatic Change 40: 135-62.

Six J, Feller C, Denef K, et al. 2002. Soil organic matter, biota and aggregation in temperate and tropical soils - effects of notillage. Agronomie 22: 755-75.

Tilman D, Reich PB, Knops J, et al. 2001. Diversity and productivity in a long-term grassland experiment. Science 294: 843-45.

USDA Farm Service Agency. Conservation Reserve Programmonthly acreage report 08-25-2006. http://165.221.16.19/ crpstorpt/08Approved/rmepegg/MEPEGGR1.htm. Viewed 29 Oct 2009. 